\title{
Changes in the Rate of Lipid Peroxidation in Plasma and Selected Blood Antioxidants before and during Pregnancy in Ewes
}

\author{
Mine Erisir ${ }^{1}$, Fulya Benzer ${ }^{2}$, Fatih M. Kandemir ${ }^{1}$ \\ ${ }^{1}$ Department of Biochemistry, Faculty of Veterinary Medicine, University of Firat, \\ Elazig-Turkey \\ ${ }^{2}$ Veterinary Control and Research Institute, Elazig-Turkey
}

Received May 12, 2008

Accepted March 9, 2009

\begin{abstract}
Pregnancy is a condition that favours oxidative stress. The aim of this study was to evaluate the oxidant and antioxidant status by measuring glutathione peroxidase (GSH-Px), catalase (CAT) activities and malondialdehyde (MDA) and glutathione (GSH) concentrations before and during pregnancy in ewes. Twelve healthy female and two healthy male Awassi sheep, aged 4-5 years, weighing approximately 50 - $55 \mathrm{~kg}$ each, were used in the study. The ewes' blood samples were taken before synchronization and during pregnancy (on $25^{\text {th }}$ days of each month of pregnancy). Plasma MDA concentrations in the $2^{\text {nd }}$ and $3^{\text {rd }}$ months of pregnancy in ewes were lower than in the $1^{\text {st }}, 4^{\text {th }}, 5^{\text {th }}$ months of pregnancy and in the non-pregnant ewes. GSH concentrations and GSH-Px activities during pregnancy were increased $(P<0.01)$. GSH concentrations and GSH-Px activities were the highest in the $2^{\text {nd }}$ and $3^{\text {rd }}$ months of pregnancy. CAT activities were decreased after the $1^{\text {st }}$ month of pregnancy in ewes $(P<0.001)$. They were the lowest in the $2^{\text {nd }}$ and $3^{\text {rd }}$ months of pregnancy. The findings of our study show decreased CAT activities and elevated GSH concentrations and GSH-Px activities after the $1^{\text {st }}$ month of pregnancy in ewes. These changes in the indicators under study may indicate a predisposition to oxidative stress in the $2^{\text {nd }}$ and $3^{\text {rd }}$ month of pregnancy in ewes.
\end{abstract}

Awassi sheep, pregnancy, oxidant and antioxidant status

Reactive oxygen species (ROS) are unavoidable intermediates produced during metabolism. Their concentration and balance between their production and degradation are controlled by enzymatic and non-enzymatic defence mechanisms (Sies 1993).

The natural defence mechanisms against free radicals consist of enzymatic antioxidants like glutathione peroxidase (GSH-Px), superoxide dismutase (SOD), catalase (CAT) and non-enzymatic antioxidants like glutathione (GSH), ascorbate, urate, vitamin E and beta carotene (Miller et al. 1993).

GSH-Px (EC 1.11.1.9) is the most effectual antioxidant in erythrocytes and catalyses reduction of hydrogen peroxide and organic peroxides like lipid peroxides. CAT (EC 1.11.1.6) together with GSH-Px is responsible for the degradation of hydrogen peroxide (Ursini and Bindoli 1987).

Lipid peroxidation is a non-enzymatic chain reaction based on oxidation of mainly unsaturated fatty acids and is associated with the presence of ROS. It leads to the creation of lipid peroxides and other intermediates. These intermediates may influence the properties of cell membranes and their physiological functions (Halliwell and Gutteridge 1985). The most common of these intermediates are malondialdehyde (MDA) and 4-hydroxynonenal (Comporti 1989).

Pregnancy is a period in life when oxidative stress can be expected due to a high energy demand and increased oxygen requirement (Gitto et al. 2002.). While pregnancy is considered to be a physiological event, the alterations in the biochemical status in pregnancy and pregnancy complications, such as pre-eclampsia, eclampsia, abortion, premature birth or hypertension, have gained importance considering the influence of lipid peroxidation on these processes (Arikan et al. 2001). In literature, information about the oxidant and

Address for correspondence:

Mine ERİSİR, Ph. D.

Assoc. Prof. of Biochemistry

Department of Biochemistry

College of Veterinary Medicine

Firat (Euphrates) University

Phone: +90-424 237-0000, ext.3960

Fax: +90-424 238-8173

ELAZIĞ, 23119 TURKEY

E-mail: mineerisir@yahoo.com

http://www.vfu.cz/acta-vet/actavet.htm 
antioxidant status before and during pregnancy in ewes is quite limited (Oztabak et al. 2005). Therefore, our aim was to investigate the changes of MDA concentrations in plasma and of 2 anti-oxidant enzyme (GSH-Px, CAT) activities, glutathione concentrations in blood before and during pregnancy in ewes.

\section{Materials and Methods}

Chemicals

All chemicals were obtained from Sigma Chemical Inc. and all organic solvents from Merck Chemical Inc. All reagents were in analytical grade.

Animals and Samples

The experiment was carried out on 12 female clinically healthy Awassi sheep, weighing approximately $50-55 \mathrm{~kg}$ and $4-5$ years of age in the Research and Practice Farm of Firat University. The animals were handled according to the Ethical Board guidelines of Firat University. They were given the diet ration and water ad libitum. The oestrus cycle of the ewes was synchronised by the application of sponges containing medroxyprogesteroneacetate (MPA), which were inserted into the vagina. The sponges were removed 14 days later and $500 \mathrm{IU}$ of pregnant mare serum gonadotrophin (PMSG) was intramuscularly administered to all ewes. Twenty-four h after the PMSG injection, two rams were added to the group and allowed to mate with the ewes. The ewes' blood samples were taken before synchronization and during pregnancy (on $25^{\text {th }}$ days of each month of pregnancy). Jugular blood samples were collected into sterile blood collecting tubes with heparin from all ewes. Whole blood was separated for GSH-Px and GSH assays. The remaining blood was immediately centrifuged at $1500 \mathrm{~g}$ for $5 \mathrm{~min}$. The erythrocytes and plasma were collected separately for CAT and MDA assays, respectively. All samples were kept at $-25^{\circ} \mathrm{C}$ pending analysis. The variables were measured monthly within 15 days after sampling.

Whole blood GSH-Px activity was measured by the method of Beutler (1975) in which cumene hydroperoxide was used as substrate. Oxide glutathione (GSSG) produced by the action of erythrocyte GSH-Px and cumene hydroperoxide, was reduced by glutathione reductase and NADPH. The decrease of the NADPH concentration was measured at $340 \mathrm{~nm}$. The enzyme activity in erythrocytes was expressed as $\mu \mathrm{kat}$ per $\mathrm{g}$ of $\mathrm{Hb}\left(\mu \mathrm{kat} \cdot \mathrm{g}^{-1} \mathrm{Hb}\right)$.

Erythrocyte CAT activity were determined according to the method of Aebi (1984) and expressed as kat $\cdot \mathrm{g}^{-1}$ $\mathrm{Hb}$. The decomposition of $\mathrm{H}_{2} \mathrm{O}_{2}$ can be directly followed by the decrease of absorbance at $240 \mathrm{~nm}$. The difference in absorbance at $240 \mathrm{~nm}$ per time unit allows determining the CAT activity.

The concentration of reduced glutathione was assayed by the method of Beutler et al. (1963) and expressed as $\mu \mathrm{mol} \cdot \mathrm{g}^{-1} \mathrm{Hb}$. The method is based on the capacity of sulphhydryl groups present in whole blood to react with 5,5 '-dithiobis-(2-nitrobenzoic acid) (Ellmann's reagent) and form a yellow dye with maximum absorbance at $412 \mathrm{~nm}$.

Haemoglobin $(\mathrm{Hb})$ concentration was determined according to cyanmethaemoglobin method (Fairbanks and Klee 1986).

The end-product of polyunsatured fatty acid peroxidation, MDA, which reacts with thiobarbituric acid in serum samples, was determined by the methods of Satoh (1978) and Yagi (1984). Reaction of malondialdehyde (MDA) with thiobarbituric acid (TBA) has been applied widely to assess lipid peroxidation in biological material. The reaction yields a red MDA-TBA adduct, the product of $2 \mathrm{~mol}$ of TBA plus $1 \mathrm{~mol}$ of MDA. The coloured complex can be quantified spectrophotometrically from its visible absorbance (max $532 \mathrm{~nm})$ and is readily extractable into organic solvents such as butanol. The values of MDA reactive material were expressed as MDA quantities for plasma volume $\left(\mathrm{nmol} \cdot \mathrm{ml}^{-1}\right.$ plasma).

Statistical analysis

Results were expressed as mean \pm SEM. Analysis of repeated measures followed by Duncan test was used to determine whether there were significant differences among the groups. Differences were considered significant when $P$ values were less than 0.05 .

\section{Results}

The mean glutathione peroxidase, catalase activities and malondialdehyde, glutathione concentrations before and during pregnancy in ewes are given in Table 1.

Plasma MDA concentrations in the $2^{\text {nd }}$ and $3^{\text {rd }}$ months of pregnancy in ewes were lower than in the $1^{\text {st }}, 4^{\text {th }}, 5^{\text {th }}$ months of pregnancy and in the non-pregnant ewes. GSH concentrations and GSH-Px activities during pregnancy were significantly increased $(P<0.01)$. GSH concentrations and GSH-Px activities were the highest in the $2^{\text {nd }}$ and $3^{\text {rd }}$ months of pregnancy. However, CAT activities were significantly decreased after the $1^{\text {st }}$ month of pregnancy in ewes $(P<0.001)$. They were the lowest in the $2^{\text {nd }}$ and $3^{\text {rd }}$ months of pregnancy. 
Table 1. Glutathione peroxidase (GSH-Px), catalase (CAT) activities and malondialdehyde (MDA), glutathione $(\mathrm{GSH})$ levels before pregnancy and during pregnancy in ewes $(\mathrm{n}=12)$.

\begin{tabular}{|c|c|c|c|c|c|c|c|}
\hline & \multirow{2}{*}{ Non-pregnant } & \multicolumn{5}{|c|}{ Pregnant (months) } & \multirow{2}{*}{$P$} \\
\hline & & $1^{\text {st }}$ & $2^{\text {nd }}$ & $3^{\text {rd }}$ & $4^{\text {th }}$ & $5^{\text {th }}$ & \\
\hline 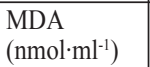 & $2.99 \pm 0.52$ & $2.69 \pm 0.49$ & $1.45 \pm 0.14$ & $1.71 \pm 0.17$ & $2.79 \pm 0.23$ & $2.25 \pm 0.29$ & NS \\
\hline $\begin{array}{l}\text { GSH } \\
\left(\mu \mathrm{mol} \cdot \mathrm{g}^{-1} \mathrm{Hb}\right)\end{array}$ & $0.68 \pm 0.18^{\mathrm{a}}$ & $1.10 \pm 0.15^{\mathrm{a}}$ & $5.00 \pm 0.70^{\mathrm{b}}$ & $3.55 \pm 0.43^{\mathrm{c}}$ & $2.58 \pm 0.22^{\mathrm{c}}$ & $2.63 \pm 0.34^{\mathrm{c}}$ & $* *$ \\
\hline $\begin{array}{l}\text { GSH-Px } \\
\left(\mu \mathrm{kat} \cdot \mathrm{g}^{-1} \mathrm{Hb}\right)\end{array}$ & $6.58 \pm 0.42^{\mathrm{a}}$ & $8.31 \pm 0.39^{b}$ & $12.23 \pm 0.29^{c}$ & $12.79 \pm 0.33^{\mathrm{c}}$ & $8.36 \pm 0.45^{\mathrm{b}}$ & $8.57 \pm 0.49^{b}$ & $* *$ \\
\hline $\begin{array}{l}\text { CAT } \\
\left(\mathrm{kat} \cdot \mathrm{g}^{-1} \mathrm{Hb}\right)\end{array}$ & $47.3 \pm 3.3^{\mathrm{a}}$ & $47.2 \pm 2.6^{\mathrm{a}}$ & $16.2 \pm 1.6^{\mathrm{b}}$ & $14.9 \pm 0.6^{b}$ & $38.0 \pm 3.1^{\mathrm{c}}$ & $31.6 \pm 2.2^{\mathrm{c}}$ & *** \\
\hline
\end{tabular}

Values with different superscripts within the same line were significant $(P<0.05)$

NS: Non significant

$* * P<0.01$

$* * * P<0.001$

\section{Discussion}

An elevation of various indices of oxidative stress during the physiological course of pregnancy has been shown (Arikan et al. 2001; Djordjevic et al. 2004; Little and Gladen 1999). During pregnancy, oxidative stress has been associated with reproductive problems such as pre-eclampsia and abortion (Little and Gladen 1999; Poston and Raijmakers 2004).

In rats and humans, high concentrations of lipid peroxidation products have been measured in normal pregnancy, but controversial information has been available on the oxidative and antioxidative status in normal pregnancy (Arikan et al. 2001; Little and Gladen 1999; Djordjevic et al. 2004; Nakai et al. 2000; Yoshioka et al. 1987). Numerous studies compared healthy pregnant and non-pregnant women (Arikan et al. 2001; Djordjevic et al. 2004; Nakai et al. 2000); all found greater lipid peroxide concentrations in the pregnant women. The plasma MDA concentrations in pregnant women in the third trimester were significantly higher than in the non-pregnant women (Arikan et al. 2001; Djordjevic et al. 2004; Nakai et al. 2000). Peroxidation in the third trimester was significantly higher than in the first and second trimesters (Carine et al. 1993; Djordjevic et al. 2004). Pregnancy is characterized by increased lipid peroxidation. On the other hand, Balal et al. (2004) have demonstrated that the plasma MDA concentrations in pregnant women in the third trimester were similar to the non-pregnant ones. Castillo et al. (2005) reported that mean MDA concentrations did not different significantly among weeks 10, 6, 2, 1 before calving and weeks 1, 2 after calving and late lactation in dairy cows.

Only two investigations reported decreasing lipid peroxides during pregnancy (Uotila et al. 1991; Naziroglu et al. 2004). Uotila et al. (1991) reported that lipid peroxide concentrations tended to decrease in the progression of pregnancy in women. Naziroglu et al. (2004) also reported that the MDA in plasma was negatively affected on day 20 of pregnancy in rats. In the present study it was also found that plasma MDA concentrations in the $2^{\text {nd }}$ and $3^{\text {rd }}$ month of pregnancy in ewes were lower than in the $1^{\text {st }}, 4^{\text {th }}, 5^{\text {th }}$ month of pregnancy and in the non-pregnant ewes. Our results on MDA concentrations do not show the expected increase during pregnancy in ewes. The decreased plasma MDA concentrations may be due to the increased GSH concentrations and GSH-Px activities in these months. Hermes-Lima et al. (1998) proposed that the activation of antioxidant defenses, in which the actual production of oxyradicals should decrease, is a preparative mechanism against oxidative stress caused by physiological stress situations.

Glutathione and glutathione-related enzymes, as one of the major detoxification and free-radical scavenging systems, may play a role in controlling diseases (Balal et al. 2004). In our study, while GSH concentrations and GSH-Px activities after the $1^{\text {st }}$ month 
of pregnancy in ewes were significantly increased, CAT activities were significantly decreased. Similarly, another study (Oztabak et al. 2005) has shown that while plasma GSH-Px activities in pregnant ewes on days 148 of pregnancy were higher than in the non-pregnant ewes, plasma CAT activities were lower and plasma TBARS concentrations were not different. Gaál et al. (2006) reported that no significant differences were found in the MDA concentration and GSH-Px activity in red blood cells at calving compared to the pre- and post-calving periods in dairy cows, but significantly higher superoxide dismutase activity. There are conflicting reports regarding antioxidant activity changes throughout gestation in humans and rats. Several researchers have suggested that during normal pregnancy an increase or a decrease or no change in the antioxidant concentrations occurs. Some studies have reported an increase of the GSH-Px in pregnancy (Djordjevic et al. 2004; Uotila et al. 1991), yet others have indicated either no significant change (Arikan et al. 2001; Balal et al. 2004; Nakai et al. 2000; Naziroglu et al. 2004) or a reduction (Behne and Wolters 1979). The reports on GSH concentrations during pregnancy are also controversial: some investigators showed an increase (Németh et al. 2001; Wisdom et al. 1991), whereas others reported a decrease (Arikan et al. 2001) or no significant change (Naziroglu et al. 2004) during pregnancy. Németh et al. (2001) suggested that an increased GSH concentration in pregnant women was an adaptation to maintain the adequate redox milieu of the red blood cells. Likewise, it is possible that such changes are required to guard the pregnant woman against a scenario of increased free radical production (Wisdom et al. 1991). CAT activities in the reports were also variable (Djordjevic et al. 2004; Naziroglu et al. 2004). We can consider that each antioxidant may be affected differently in pregnancy. Our results indicate that pregnancy causes significant changes in the protective antioxidant mechanisms of ewes' blood.

The susceptibility of cells to oxidative stress is a function of the overall balance between the degree of oxidative stress and the antioxidant defense capability. It is possible that during gestation, the increase in antioxidant activity occurs in response to normal oxidative stress due to pregnancy (Nakai et al. 2000). Under physiological condition, antioxidant defense systems have evolved to counterbalance their toxic actions by limiting the amount of lipid peroxides that can be formed (Little and Gladen 1999).

Moreover, the placental environment is one of enhanced oxidative stress that induces protective mechanisms against free radicals as gestation progresses. The plasma free radical trapping and antioxidant potential are able to counteract oxidative stress in normal pregnancy through enzymatic induction and activity as well as through non-enzymatic free radical protectors and scavengers (Casanueva and Viteri 2003).

We suggest that the increased GSH concentrations and GSH-Px activities and decreased concentrations of CAT activities may reflect oxidative stress in pregnant ewes. Particularly, the $2^{\text {nd }}$ and $3^{\text {rd }}$ month of pregnancy may increase susceptibility to oxidative stress in ewes. Pregnant ewes' protective systems (especially GSH-Px and GSH) adapt very early to maintain a stable balance.

\section{Změny intenzity lipoperoxidace a obsahu vybraných antioxidantů v krvi bahnic před zabřeznutím a $\mathrm{v}$ průběhu gravidity}

Gravidita je období vyšší predispozice ke vzniku oxidačního stresu. Cílem této studie bylo zhodnotit oxidační a antioxidační status měřením aktivity glutathionperoxidázy (GSH-Px), katalázy (CAT) a koncentrací malondialdehydu (MDA) a glutathionu (GSH) před a během gravidity u bahnic. K experimentu bylo použito dvanáct ovcí a dva berani plemene Awassi v dobrém zdravotním stavu, ve věku 4 - 5 let, o hmotnosti 50 - $55 \mathrm{~kg}$. Vzorky krve byly ovcím odebrány před zabřeznutím a během gravidity (25. den v každém měsíci březosti). Hladiny MDA v krevní plazmě byly nižší v druhém a třetím měsíci březosti, než ve vzorcích odebraných 1., 4. a 5. měsíc gravidity a v krevní plazmě jalových ovcí. Hladina 
GSH a aktivita GSH-Px během gravidity byly významně zvýšené $(\mathrm{P}<0.01)$, maximálních hodnot dosahovaly tyto ukazatele ve 2. a 3. měsíci březosti. Aktivita CAT byla významně snížená po prvním měsíci gravidity bahnic $(\mathrm{P}<0.001)$ a nejnižších hodnot dosahovala ve 2. a 3. měsíci březosti. $V$ této studii bylo zjištěno, že po prvním měsíci gravidity bahnic je nižší aktivita CAT, zatímco koncentrace GSH a aktivita GSH-Px jsou zvýšené. Tyto změněné ukazatele mohou signalizovat náchylnost ke vzniku oxidačního stresu ve 2. a 3. měsíci březosti bahnic.

\section{Acknowledgement}

We are grateful to FUVEM (Research and Practice Directorship of Farm of Firat University) for their cooperation.

\section{References}

Aebi H 1984: Catalase in vitro. Methods Enzymol 105: 121-126

Arikan S, Konukoglu D, Arıkan Ç, Akcay T, Davas I 2001: Lipid peroxidation and antioxidant status in maternal and cord blood. Gynecol Obstet Invest 51: 145-149

Balal M, Canacankatan N, Paydas S, Seyrek N, Karayaylalı I, Kayrın L 2004: Oxidative-antioxidative system in peripartum acute renal failure and preeclampsia-eclampsia. Ren Fail 24: 625-632

Behne D, Wolters W 1979: Selenium content and glutathione peroxidase activity in the plasma and erythrocytes of non-pregnant and pregnant women. J Clin Chem Clin Biochem 17: 133-135

Beutler E 1975: Red cell metabolism. In: Beutler E. (Ed.): A manual of biochemical methods. Grunef and Strottan, New York, pp. 67-69

Beutler E, Duron O, Kelly BM 1963: Improved method for the determination of blood glutathione. J Lab Clin Med 61: 882-888

Carine D, Loverco G, Greko P, Capuno F, Selvaggi L 1993: Lipid peroxidation products and antioxidant enzymes in red blood cells during normal and diabetic pregnancy. Eur J Obstet Gynecol Reprod Biol 51: 103-109

Casanueva E, Viteri FE 2003: Iron and oxidative stress in pregnancy. J Nutr 133: 1700-1708

Castillo C, Hernandez J, Bravo A, Lopez-Alonso M, Pereira V, Benedito JL 2005: Oxidative status during late pregnancy and early lactation in dairy cows. Vet J 169: 286-292

Comporti M 1989: Three models of free radical-induced cell injury. Chem Biol Interact 72: 1-56

Djordjevic A, Spasic S, Jovanovic-Galovic A, Djordjevic R, Grubor-Lajsic G 2004: Oxidative stress in diabetic pregnancy: SOD, CAT and GSH-Px activity and lipid peroxidation products. J Matern-Fetal Neonatal Med 16: $367-372$

Farrbanks VF, Klee GG 1986: Biochemical aspects of hematology. In: Tietz NW (Ed.): Textbook of clinical chemistry. WB Saunders Company, Philadelphia, pp. 1532-1534

Gaál T, Ribiczeyné-Szabó P, Stadler K, Jakus J, Reiczigel J, Kövér P, Mézes M, Sümeghy L 2006: Free radicals, lipid peroxidation and the antioxidant system in the blood of cows and newborn calves around calving. Comp Biochem Physiol B-Biochem Mol Biol 143: 391-396

Gitto E, Reiter RJ, Karbownik M, Tan DX, Gitto P, Barberi S, Barberi I 2002: Causes of oxidative stress in the pre- and perinatal period. Biol Neonate 81: 146-157

Halliwell B, Gutteridge JM 1985: The importance of free radicals and catalytic metal ions in human diseases. Mol Asp Med 8: 89-193

Hermes-Lima M, Storey JM, Storey KB 1998: Antioxidant defenses and metabolic depression. The hypothesis of preparation for oxidative stress in land snails. Comp Biochem Physiol B-Biochem Mol Biol 120: 437-448

Little RE, Gladen BC 1999: Levels of lipid peroxides in uncomplicated pregnancy: a review of the literature. Reprod Toxicol 13: 347-352

Miller JK, Brzezinska-Slebodzinska E, Madsen FC 1993: Oxidative stress, antioxidants and animal function. J Dairy Sci 76: 2812-2823

Nakai A, Oya A, Kobe H, Asakura H, Yokota A, Koshino T, Araki T 2000: Changes in maternal lipid peroxidation levels and antioxidant enzymatic activities before and after delivery. J Nippon Med Sch 67: 434-439

Naziroglu M, Simsek M, Kutlu M 2004: Moderate exercise with a dietary vitamin C and E combination protects against streptozotocin-induced oxidative damage to the blood and improves fetal outcomes in pregnant rats. Clin Chem Lab Med 42: 511-517

Németh I, Orvos H, Boda D 2001: Blood glutathione redox status in gestational hypertension. Free Radic Biol Med 30: 715-721

Oztabak K, Civelek S, Ozpınar A, Burcak G, Esen F 2005: The effects of energy restricted diet on the activities of plasma $\mathrm{Cu}-\mathrm{Zn}$ SOD, GSH-Px, CAT and TBARS concentrations in late pregnant ewes. Turk J Vet Anim Sci 29: $1067-1071$

Poston L, Raijmakers MT 2004: Trophoblast oxidative stress, antioxidants and pregnancy outcome - a review. Placenta 25: $72-78$ 
Satoh K 1978: Serum lipid peroxide in cerebrovascular disorders determined by a new colorimetric method. Clin Chim Acta 90: $37-43$

Sies H 1993: Strategies of antioxidant defense. Eur J Biochem 215: 213-219

Uotila J, Tuimala R, Aarnio T, Pyykko K, Ahotupa M 1991: Lipid peroxidation product, selenium-dependent glutathione peroxidase and vitamin E in normal pregnancy. Eur J Obstet Gynecol Reprod Biol 42: 95-100

Ursini F, Bindoli A 1987: The role of selenium peroxidases in the protection against oxidative damage of membranes. Chem Phys Lipids 44: 255-276

Wisdom SJ, Wilson R, McKillop JH, Walker JJ 1991: Antioxidant systems in normal pregnancy and in pregnancyinduced hypertension. Am J Obstet Gynecol 165: 1701-1704

Yagi K 1984: Assay for blood plasma or serum, Methods Enzymol 105: 328-331

Yoshioka T, Motoyama H, Yamasaki F, Ando M, Takehara Y, Yamasaki M 1987: Lipid peroxidation and vitamin E levels during pregnancy in rats. Biol Neonate 52: 223-231 